\title{
Epiphytes of Captured Red Sea Turtles (Red Turtles): Delhi Bay, Albania
}

\author{
Vilma PIROLI ${ }^{1}$, Idriz HAXHIU ${ }^{2}$ \\ ${ }^{1}$ University of Shkoder "Luigj Gurakuqi”, Sheshi 2 Prilli, Shkoder, Albania \\ vilmapiroli@gmail.com
}

${ }^{2}$ Herpetofauna Albanian Society, Lagja Sulhaxhi, 1032 Vore, Albania

\begin{abstract}
This study represents the results of the epibionts found on 157 loggerhead turtles by-caught at Drini bay. We found the presence of the organisms living throughout their lifetime in the host, as well as those who use the turtle for a part of their lifecycle. In total eight taxa of epibionts, including algae, bivalves, annelids and crustaceans were found living on the turtles, of which all except for the leeches (Ozobranchus spp.) represent a commensally relationship with the host. Chelonibia testudinaria was the most frequently observed turtle epibiont and barnacle in this study.
\end{abstract}

Keywords: Epibionts, loggerhead turtle, Drini bay, Caretta caretta, by-catch

\section{Introduction}

Sea turtles are used as floating settlement structures by certain marine species of flora and fauna that need areas to settle for part or all of their life cycle (Frazier et al., 1985; Dodd, 1988; Báez et al., 2001). This makes the sea turtles a mobile ecosystem in the ocean that due to its movement offer to species like algae an attachment substrate, and species like barnacles and crabs, movement to pelagic and neritic areas optimizing suspension and filter feeding performed by these species (Frick et al., 2004). The presence and characteristics of the epibionts are studied for a better understanding of the ecology and behavior of the turtle that is the host.

The epibiont associations in most cases represent commensally relationships, parasitism is only found in turtles with the presence of leeches (Ozobranchus spp.) which feeds on the blood of the turtle (George, 1997).

The most commonly documented epibionts of sea turtles are the sessile and motile crustaceans. These animals are found in both debilitated and healthy turtles. Mass-colonization of the debilitated turtles is suggested to happen while the turtle is lethargic by other factors (Deem et al., 2009) and do not perform self-grooming (Frick and McFall, 2007) as an epibionts controlling behavior as healthy turtles do.

The structure of the epibiontic community in a sea turtle is affected by the seasonal migration (Reich et al., 2010) symbiotic cleaning associations with other animals (Dellinger et al., 1997; Frick et al., 2004; Frick et al., 2000; Sazima et al., 2010) and by removing away the epibionts by scraping on hard, submerged structures and substrates (Frick and McFall, 2007).

Sea turtle epibiontic community has been studied for both loggerhead and green turtle in the Mediterranean. This information comes from studies conducted on nesting loggerhead turtles (Gramentz, 1988; Fuller et al., 2010), from stranded turtles (Kitsos et al., 2003; Scaravelli et al., 2003; Kitsos et al., 2005; Karaa et al., 2011; Domènech et al., 2016; Domènech et al., 2015), and by-caught turtles (Casale et al., 2004; Zakhama-Sraieb et al., 2010; Casale et al., 2012). In Albania, the epibiontic community has been studied for the loggerhead turtle and the green turtle from the Adriatic coast (Piroli and Haxhiu, 2013).

The present study examines the occurrence of epibionts on loggerhead turtles frequenting neritic foraging grounds in the Drini bay (Albania).

\section{Materials and Methods}

The results represented in this study were collected from 157 loggerhead turtles Caretta caretta by-caught at the Drini bay during the period April-October 2015 and with the presence of the epibionts. Each turtle curved carapace length $\left(\mathrm{CCL}_{n-t}\right)$ was measured (Bolten, 1999), the turtle was marked with flipper tags bearing unique serials, was photographed, and then the epibionts were identified, removed and preserved in alcohol $70 \%$. The body surface of the turtle was divided in the carapace, plastron, head, neck, supra-caudal and limbs. Epibionts were detected by the naked eye while in the turtle or by a stereomicroscope for the samples preserved.

\section{Results and Discussions}

The loggerhead turtles $\mathrm{CCL}_{\mathrm{n}-\mathrm{t}}$ ranged $44.00 \mathrm{~cm}$ to $87.00 \mathrm{~cm}$ (mean $\mathrm{CCL}=67,13 \mathrm{~cm}, \mathrm{sd}=7,95, \mathrm{n}=157$ ). The presence of the epibionts was found in $62,42 \%$ of the turtles by-caught during the period covered by this study. We observed 8 taxa of epibionts that included algae, bivalves, annelids, amphipods, and lepadomorph and balanomorph barnacles.

The algae (species not identified) were found in $13.83 \%$ of the turtles with epibionts. A preference of the carapace of the turtle was found for their settlement (Tab. 1). A study from the Adriatic coast of Albania found the presence of the macroalgae in the sea turtles (Piroli and Haxhiu, 2013) while another one from the northern Aegean sea found presence on the anterior and the posterior part of the dorsal surface of the carapace and on the marginal plates (Kitsos et al., 2005). This distribution is suggested to be attributed to the light 
requirements of these species (Gramentz, 1988). The results of this study support this idea.

Two species of bivalves Mytilus galloprovincialis and Ostrea edulis were identified by this study as epibionts of the by-caught turtles. The frequency of the occurrence of these bivalves was low compared to algae. The frequency of the occurrence of these epibionts was low even for other studies from bycaught turtles in Albanian coast (Piroli and Haxhiu, 2013), stranded dead turtles in the northern Aegean sea (Kitsos et al., 2005), while no evidence of these species was reported from Central Mediterranean (D'Addario et al., 2012).

Representatives of Polychaeta and Hirudinea worms were found in $19.10 \%$ of the turtles. The polychaeta was found settled in the carapace and the supra-caudal region (the ventral surface of the supra-caudal scutes of the carapace) with a distingue preference of the carapace. The Hirudinea worms, Ozobranchus spp. were found both in egg and adult stage. The eggs were found attached in the hard part of the body of the turtle, posterior plastron and supra-caudal region, while the adults were found in the soft body parts such as tail, limb and neck region. Kitsos et al., (2005) also reported presence of the Ozobranchus margoi attached to various fleshy parts of the turtle's body, while another study from the Albanian coastline reported a higher occurrence of the leeches for almost same sample size $(8 \%, n=164)$ compared to this study. This occurrence is suggested to the parasitic relationship between the two species (George, 1997).

Caprella andreae is the amphipod specie found by this study in $1.91 \%$ of the turtles. This specimen was found only on the carapace region and in those turtles with the presence of the macro algae. Even other studies from the Mediterranean report the amphipods (Kitsos et al., 2005; Casale et al., 2012) as a macroalgal associated fauna that always show the same distributional pattern as their host as they use it for shelter and food (Caine, 1986).

Lepadomorph and balanomorph barnacles were found as epibionts of the loggerhead turtle by this study. The balanomorph barnacles resulted the epibionts with the highest occurrence on the turtle, same result was reported for another study in the southeast Adriatic (Piroli and Haxhiu, 2013). The presence of the lepadomorph barnacle Lepas anatifera and the balanomorph barnacle Chelonibia testudinaria, as well as the presence of the mud on the turtles by-caught in the stavniks of Drini bay suggest these turtles frequent benthic habitats of the bay. Higher occurrence of such species is found and associated with turtles assumed to frequent benthic habitats and shallow waters even by other studies in the Mediterranean (Casale et al., 2012; Casale et al., 2004) and Atlantic (Stamper et al., 2005).

Table 1: Composition of the organism assemblage associated with loggerhead turtle (Caretta caretta)

\begin{tabular}{|c|c|c|c|c|c|c|c|c|}
\hline \multirow{2}{*}{ Epibiont } & \multirow{2}{*}{$F(\%)$} & \multicolumn{7}{|c|}{$\%$ of presence in different parts of the turtle } \\
\hline & & $\mathrm{Ca}$ & Pla & $S C$ & $T$ & $H$ & $L$ & $N$ \\
\hline ALGAE & 13.38 & 100.00 & 0.00 & 0.00 & 0.00 & 0.00 & 0.00 & 0.00 \\
\hline \multicolumn{9}{|l|}{ BIVALVIA } \\
\hline Ostrea edulis (Linnaeus, 1758) & 1.27 & 100.00 & 0.00 & 0.00 & 0.00 & 0.00 & 0.00 & 0.00 \\
\hline Mytilus galloprovincialis (Lamarck, 1819) & 1.91 & 100.00 & 0.00 & 0.00 & 0.00 & 0.00 & 0.00 & 0.00 \\
\hline \multicolumn{9}{|l|}{ ANNELIDA } \\
\hline Polychaeta & 15.92 & 84.62 & 0.00 & 15.38 & 0.00 & 0.00 & 0.00 & 0.00 \\
\hline \multicolumn{9}{|l|}{ Hirudinea } \\
\hline Ozobranchus spp. & 3.18 & & & & & & & \\
\hline Ozobranchus spp. eggs & & 0.00 & 40.00 & 60.00 & 0.00 & 0.00 & 0.00 & 0.00 \\
\hline Ozobranchus spp. adults & & 0.00 & 0.00 & 0.00 & 60.00 & 0.00 & 20.00 & 20.00 \\
\hline \multicolumn{9}{|l|}{ CRUSTACEA } \\
\hline \multicolumn{9}{|l|}{ Amphipoda } \\
\hline Caprella andreae (Mayer, 1890) & 1.91 & 100.00 & 0.00 & 0.00 & & 0.00 & 0.00 & 0.00 \\
\hline \multicolumn{9}{|l|}{ Cirripedia Thoracica } \\
\hline Balanomorph barnacles & 54.78 & 55.07 & 34.06 & 4.35 & & 2.17 & 3.62 & 0.72 \\
\hline Lepidomorph barnacles & 3.18 & 100.00 & 0.00 & 0.00 & & 0.00 & 0.00 & 0.00 \\
\hline
\end{tabular}

$\mathrm{F}(\%)$ - frequency of occurrence in the turtles by-caught during the period covered by this study; Ca- Carapace; P- plastron; SC- Supra-caudal; T- Tail; H- Head; L- Limbs; N- Neck.

Chelonibia testudinaria occurred mainly on the carapace, and it was the only epibiont identified in all parts of the turtle (Tab. 1). This study did not identify a preference of settling on any specific part of the carapace. Different studies (Caine, 1986; Gramentz, 1988; Kitsos et al., 2005; Pfaller et al., 2006; Casale et al., 2012) suggest a nonuniform distribution of epibiont species on the turtle's body, while some of them reported a preferential settlement location exhibited by the Chelonibia testudinaria. Karaa et al. (2012) found Chelonibia testudinaria was prevalent in all turtle's body, mostly on the entire carapace surface, while there were other studies that found it mostly on the marginal scutes (Frick and Slay, 2000; Kitsos et al., 2005), or from the posterior third of the carapace region (Caine, 1986; Frick et al., 1998). This species-specific locations is suggested to not just be an opportunistic settling by the barnacle larvae, but it is the best position for the different needs of barnacle species (Casale et al., 2012), because the positioning of the epibionts on the anterior part of the body may influence the suspension feed due to the stronger water flow (Frick et al., 2011).

Chelonibia testudinaria was the most frequently observed turtle barnacle in this study. This specimen is reported to be the most frequently observed barnacle even for other studies 
from the Mediterranean (Kitsos et al., 2003; Casale et al., 2004; Kitsos et al., 2005; Karaa et al., 2011).

Lepas anatifera is found by this study in the carapace of the loggerhead turtles, but in a low frequency of the occurrence compared to the other barnacle Chelonibia testudinaria. Lepas anatifera is reported as an epibiont of loggerheads in different regions of the Mediterranean Sea (Relini, 1980; Gramentz, 1988; Koukouras and Matsa, 1998; Kitsos et al., 2003; Kitsos et al., 2005; Badillo, 2007; Prazzi et al., 2009; Fuller et al., 2010; Karaa et al., 2011). This study found it in clusters only in the carapace region, while the attachment mainly in the carapace (marginal plates) was found even by other studies (Karaa et al., 2011; Piroli and Haxhiu, 2013) which reported the presence even in the plastron (inframarginal scutes) and in small numbers on the head.

\section{Acknowledgements}

These results were made possible by the NETCET project supported by IPA CBC program of the EU. The authors gratefully acknowledge the support provided by this project and all those who have supported and volunteered during the period covered by this study.

\section{References}

[1] Badillo J.F. (2007): Epizoitos y parasitos de la tortuga boba (Caretta caretta) en el Mediterraneo occidental. Dissertation. Valencia. Universitat de Valencia: 262.

[2] Báez J. C., Camiñas J. A., J. Valeiras, F. Conde, A. Flores-Mya, (2001): First record of the epizoic red seaweed Polysiphonia carettia, Hollenberg in the Mediterranean sea". Acta Botanica Malacitana: 26.

[3] Bolten A. B. (1999): Techniques for measuring sea turtles. In: Eckert K. L., Bjorndal K. A., AbreuGrobois F. A., Donnelly M. (eds.), Research and management techniques for the conservation of sea turtles: 110-114. (IUCN/SSC Marine Turtle Specialist Group, Washington, D.C.).

[4] Caine E. A. (1986): Carapace epibionts of nesting loggerhead sea turtles: Atlantic coast of USA. Journal Exp Mar Biol Ecol. 95: 15-26.

[5] Casale P., D’addario M., Freggi D., Argano R., (2012): Barnacles (Cirripedia, Thoracica) and associated epibionts from sea turtles in the central Mediterranean". Crustaceana 85(4): 533-549, DOI:10.1163/156854012X634393

[6] Casale P., Freggi D., Basso R., Argano R., (2004): Epibiotic barnacles and crabs as indicators of Caretta caretta distribution and movements in the Mediterranean Sea. Journal of the Marine Biological Association of the United Kingdom, 84: 1005-1006.

[7] D'Addario M., Casale P., Freggi D. (2012): Epibionts of loggerhead sea turtles, Caretta caretta, in the central Mediterranean", In T. T. Jones, B. P. Wallace, compilers. Proceedings of the Thirty-first Annual Symposium on Sea Turtle Biology and Conservation. NOAA Technical Memorandum NOAA NMFSSEFSC: 190.

[8] Deem S. L., Norton T. M., Mitchell M., Segars A., Alleman A. R., Cray C., Poppenga R. H., Dodd M., Karesh W. B. (2009): Comparison of blood values in foraging, nesting, and stranded loggerhead turtles (Caretta caretta) along the coast of Georgia, USA". Journal of Wildlife Diseases, 45: 41-56.

[9] Dellinger T., Davenport J., Wirtz P. (1997): Comparisons of social structure of Columbus crabs living on loggerhead sea turtles and inanimate flotsam". Journal of the Marine Biological Association of the United Kingdom, 77: 185-194.

[10] Dodd C.K. (1988): Synopsis of the biological data on the loggerhead sea turtle Caretta caretta (Linnaeus 1758). US Fish and Wildlife Service, Biological Reports, 88(14): 110

[11] Domènech F., Badillo F. J., Tomás J., Raga J. A., Aznar F. J (2016): Epibiont fauna of loggerhead turtles (Caretta Caretta) in the Spanish Mediterranean: A Geographical Comparison. In Belskis L., Frey A., Jenson M., LeRoux R., Stewart K. compilers. 2016. Proceedings of the Thirty-Fourth Annual Symposium on Sea Turtle Biology and Conservation. NOAA Technical Memorandum NOAA NMFS-SEFSC-701. doi:10.7289/V5/TM-SEFSC-701: 152

[12] Domènech F., Badillo F., Tomás J., Raga J., Aznar F. (2015): Epibiont communities of loggerhead marine turtles (Caretta caretta) in the western Mediterranean: Influence of geographic and ecological factors. Journal of the Marine Biological Association of the United Kingdom, 95(4): $851-861$ doi:10.1017/S0025315414001520

[13] Frazier J., Margaritoulis D., Muldoon K., Potter C.W., Rosewater J., Ruckdeschel C.A., Salas S. (1985): Epizoan communities on marine turtles 1. Bivalve and gastropod mollusks. Marine Ecology (PSZNI) 6: 127140.

[14] Frick M. G., Mcfall G. (2007): Self-grooming by loggerhead turtles in Georgia, USA. Marine Turtle Newsletter, 118: 15.

[15] Frick M. G., Slay C. K. (2000): Caretta caretta (Loggerhead sea turtle). Epizoans. Herpetological Review, 31: 102-103.

[16] Frick M. G., Williams K. L., Bolten A. B., Bjorndal K. A., Martins H. R. (2004): Diet and fecundity of Columbus crabs, Planes minutus, associated with oceanic-stage loggerhead sea turtles, Caretta caretta, and inanimate flotsam. Journal of Crustacean Biology, 24: 350-355.

[17] Frick M. G., Williams K. L., Veljacic D. (2000): Additional evidence supporting a cleaning association between epibiotic crabs and sea turtles: how will the harvest of sargassum seaweed impact this relationship? Marine Turtle Newsletter, 90: 11-13.

[18] Frick M. G., Zardus J. D., Ross A., Senko J., MontanoValdez D., Bucio-Pacheco M., Sosa-Cornejo I. (2011): Novel records and observations of the barnacle Stephanolepas muricata (Cirripedia: Balanomorpha: Coronuloidea); including a case for chemical mediation in turtle and whale barnacles. Journal of Natural History, London, 45: 629-640.

[19] Frick M.G., Williams K.L., Robinson M. (1998): Epibionts associated with nesting loggerhead sea turtles (Caretta caretta) in Georgia, U.S.A. Herpetological Review, 29: 211-214.

[20] Fuller W. J., Broderick A. C., Never R. E, Thorne P., Godley B. J. (2010): Motile homes: a comparison of 
the spatial distribution of epibiont communities on Mediterranean sea turtles. Journal of Natural History, London, 44: 1743-1753.

[21] George R. H. (1997): Health problems and diseases of sea turtles. In: Lutz P. L., Musick J. A. (eds.), The biology of sea turtles: 363-384. (CRC Marine Science Series, CRC Press, Inc., Boca Raton, Florida).

[22] Gramentz D. (1988): Prevalent epibiont sites on Caretta caretta in the Mediterranean Sea. Naturalista Siciliano, 12: 33-46.

[23] Karaa S, Jribi I, Bouain A, Bradai M. N. (2011): The first report on epizoic algae of loggerhead sea turtles, Caretta caretta, in the Gulf of Gabes-Tunisia. In Bentivegna F., Maffucci F., Mauriello V. (compilers). 2011. Book of Abstracts. 4th Mediterranean Conference of Marine Turtles Napoli - Italy: 73.

[24] Kitsos M. S., Christodoulou M., Alpakis S. K., Noidou M., Koukouras A., (2003): Cirripedia Thoracica associated with Caretta caretta (Linnaeus, 1758) in the northern Aegean Sea. Crustaceana, 76: 403-409.

[25] Kitsos M. S., Hristodoulou M. C., Arvanitidis C., Mavidis M., Kirmitzoglou I., Koukouras A. (2005): Composition of the organismic assemblage associated with Caretta caretta. Journal of the Marine Biological Association of the United Kingdom, 85: 257-261.

[26] Koukouras A., Matsa A. (1998): The thoracican cirriped fauna of the Aegean Sea: new information, check list of the Mediterranean species, faunal comparisons. Senckenbergiana Maritima, 28: 133-142.

[27] Pfaller J. B., Bjorndal K. A., Reich K. J., Williams K. L., . Frick M. G. (2006): Distribution patterns of epibionts on the carapace of loggerhead turtles, Caretta caretta. Biodiversity Records, [published online 5381: 1-4.

[28] Piroli V., Haxhiu I. (2013): Të dhëna për epibiontët e studiuar në breshkat detare, 2010. Revista shkencore Vitrina nr 15: 24-34

[29] Prazzi E., Piovano S., Pesan D., Comparetto G., Giacoma C. (2009): Preferential position of cirripeds epibiont on specimens of Caretta caretta captured in Linosa and Lampedusa waters (Pelagie Islands, Sicily, Italy). In: Demetropoulos A., Turkozan O. (eds). Proceeding of the Second Mediterranean Conference on marine turtles Kemer: Turkey: 150.

[30] Reich K. J., Bjorndal K. A., Frick M. G., Witherington B. E., Johnson C., Bolten A. B., (2010): Polymodal foraging in adult female loggerheads (Caretta caretta). Marine Biology, Berlin, 157: 113-121.

[31] Relini G. (1980): Guide per il riconoscimento delle specie animali delle acque lagunari e costiere Italiane. 2. Cirripedi Toracici. Roma: Consiglio Nazionale delle Ricerche.

[32] Sazima C., Grossman A., Sazima I. (2010): Turtle cleaners: reef fishes foraging on epibionts of sea turtles in the tropical southwestern Atlantic, with a summary of this association type. Neotropical Ichthyology, 8: 187-192.

[33] Scaravelli D., Affronte M., Costa F. (2003): Analysis of epibiont presence on Caretta caretta from Adriatic Sea. In: Margaritoulis D., Demetropoulos A. (editors). Proceedings of the First Mediterranean Conference on Marine Turtles. Barcelona Convention - Bern
Convention - Bonn Convention (CMS). Nicosia, Cyprus: 221-225

[34] Stamper M. A., Harms C., Epperly S. P., BraunMcneill J., Avens L., Stoskopf M. K. (2005): Relationship between barnacle epibiotic load and hematologic parameters in loggerhead sea turtles (Caretta caretta), a comparison between migratory and residential animals in Pamlico Sound, North Carolina. Journal of Zoo and Wild Med, 36: 635- 641.

[35] Zakhama-Sraieb R., Karaa S., Bradai M. N., Jribi I., Harfi-Cheikhrouha F. C. (2010): Amphipod epibionts of the sea turtles Caretta caretta and Chelonia mydas from the Gulf of Gabès (central Mediterranean). Marine Biodiversity Records, 3: e38. 